This is the peer reviewed version of the following article:

Fontich, X. (2016). L1 Grammar Instruction and Writing: Metalinguistic Activity as a Teaching and Research Focus. Language and Linguistics Compass, 10(5), 238-54, which has been published in final form at https://doi.org/10.1111/Inc3.12184. This article may be used for non-commercial purposes in accordance with Wiley Terms and Conditions for Self-

Archiving.

\title{
L1 grammar instruction and writing: Metalinguistic activity as a teaching and research focus
}

Xavier Fontich

Universitat Autònoma de Barcelona

xavier.fontich@uab.cat

\begin{abstract}
Some authors have noted a lack of conceptual clarity in the field of L1 grammar instruction for writing. Here "metalinguistic activity" is proposed as a concept that can contribute conceptual clarity by relating metalinguistic activity both to the reflexivity that languages afford (i.e., using language to refer to language itself) and to a sociocultural approach to languages (i.e., languages consist of semiotic tools that underpin our psychological development). I discuss how this notion is approached by Grup de Recerca sobre Ensenyament i Aprenentatge de Llengües (GREAL), the Research Group on Teaching and Learning Languages at the Autonomous University of Barcelona (Spain), and describe their seminal study of secondary students' metalinguistic activity in the context of writing. Results show that metalinguistic activity emerges at different levels (procedural, with common language, and with metalanguage). While it may not lead to students automatically writing better texts, metalinguistic activity does help them to engage in sustained discussion about text choices in the context of text production, something considered of the utmost importance in educating good writers. In conclusion, I indicate the theoretical relevance of this concept and suggest the need for more research on how to implement it effectively in the classroom.
\end{abstract}

\section{Introduction}

Studies on L1 grammar instruction and its impact on writing suggest that there is a disturbing lack of conceptual clarity in this field. They underline the need for further exploration of a number of issues that fall around the poles of the "pedagogic system" (cf. Fontich and Camps, 2014), such as teachers' subject knowledge (Watson, 2015), linguistic models (Hudson, 2010), and the process of learning (Dolz and Simard, 2009). A general assumption is that a further understanding of such issues will create conceptual clarity, which will in turn contribute to the elaboration of a so-called "pedagogic grammar" devoted to improving the use of language (cf. Andrews, 2010). Conceptual clarity would come from modifying one's theoretical assumptions in light of the analysis of data gathered through methodological procedures (Cole, 2010; cf. also 
Egar, 2009). In this paper, I will assume that the concept of "metalinguistic activity" can contribute conceptual clarity.

With regard to L1 studies, ${ }^{1}$ Karmiloff-Smith's (1992) model places first language acquisition in a process of reworking of knowledge that unfolds through various developmental stages. While the stages proceed from implicit to explicit levels, the latter are metalinguistic levels, which are nevertheless initially not accessible to consciousness, though becoming verbalizable in a progressively more specific language. According to Karmiloff-Smith (1992: 18), although the model stresses "the endogenous nature of representational redescription, clearly the process may at times be triggered by external influences." Gombert (1992) also maintains that this development is fuelled not only by internal factors but also by social ones. The influence of social factors is also highlighted by literacy studies, which confirm that language and communication are a constant focus of attention in school (cf. Roth et al. 1996). This would be especially so in relation to writing, which according to Myhill and Jones (2015: 840) "is always an act of selecting, shaping, reflecting, and revising [...] and thus draws on metalinguistic activity".

Metalinguistic activity is connected with a basic feature of natural languages: the possibility they afford for reflexion (i.e., using language to refer to language itself), what Jakobson (1960) calls "metalinguistic function". Taylor (2000) considers that the reflexive use of language does not constitute a mere second-order activity and asserts that without reflexivity, writing, translation, pragmatics, semantics, and language acquisition could not exist. Referring to Wittgenstein's (1953) "language game", Taylor (2014) asserts that a primitive language that did not afford metalinguistic remarks could not allow communication and ultimately could not stand as what we count on a language to be.

An important issue highlighted in the L1-grammar-for-writing debate has been the role linguistic models should play in a "pedagogic grammar". There seems to be general agreement about the importance of an eclectic approach rather than allegiance to a single model (Andrews, 2010). Hudson (2010) takes this idea a step further and proposes to draw on what he calls "linguistic ideas", manifested in well-established dichotomies such as synchrony-diachrony or description-prescription. In my opinion, this debate could also benefit from further exploration of the notion of metalinguistic activity. Drawing on the way reflexivity is dealt with in linguistic studies may bring about a better understanding of the nature of metalinguistic activity, thereby enabling us to better explore how to approach it as a teaching-learning tool and as a focus for research. 
Studies conducted by GREAL in primary and secondary schools have explored metalinguistic activity drawing on the model of Instructional Sequence (Camps, 2014; Milian, 2014). This model pursues the acquisition of linguistic and discursive knowledge within a frame that encourages collaborative work, makes the teaching objectives explicit, and involves students in communicative tasks. The Instructional Sequences focus on grammar issues, either from within the system (e.g., the concept of transitivity, cf. Camps and Zayas, 2006) or from writing (e.g., the concept of connectives in argumentation, cf. Camps, 2003). In all cases it aims at improving students' capacity for engaging in metalinguistic activity as a source of knowledge of language. Interestingly, this model opens up spaces to pursue fine-tuned research that may allow researchers to better understand metalinguistic activity, identify potential obstacles that hinder students' reflections, and explore possible new teaching strategies that will in turn trigger new instances of metalinguistic activity intended for renewed scrutiny. According to Camps $(2011,2014)$, this action-reflection dialectic is aimed at reaching a more robust theoretical understanding of the interplay between metalinguistic activity, grammar knowledge, and language use. Details about GREAL's work will follow the discussions of reflexivity and metalinguistic activity presented in sections 2 and 3 .

\section{Reflexivity in linguistic studies}

N.Ellis's (1998: 657) work suggests that there are two ways of approaching the study of language. On the one hand, he maintains that for some theorists "one can't have a theory about the development of something without having a theory of what that 'something' is." According to Bronckart (2008: 7), this approach requires that "the processes of noesis (of pure thought) are primary with regard to the processes of semiosis and independent and autonomous with respect to the latter" (italics in original). Human language would rely on a secondary mechanism for expression of cognitive structures, which, as primary processes of noesis, would have a natural principle. By means of this natural foundation, units of thought would be stable and the actual languages would be assumed not to play any part in their formation. In this respect, Taylor (2000) argues that in this approach reflexivity would have no role in the process of language acquisition. Rather, it would stand as a peripheral feature of language, and its disappearance might affect many of the particular cultural uses that we make of language though not language itself, "the properties of which are selfidentifying" (487). Or, as Searle (1995: 73) puts it, "Language doesn't require language in order to be language because it already is language." 
N.Ellis (1998:657) places Chomskyan tenets in this perspective: according to Chomsky (1977: 43), "No discipline can concern itself in a productive way with the acquisition and utilization of a form of knowledge without being concerned with the nature of that system of knowledge." Chomskyan tenets draw on the basic distinction of "I-Language" (internal language) and "E-Language" (external language) (Chomsky, 1986). Only the former would correspond to the reality of language, based on a genetic endowment that would account for language and language development. In accordance with the secondary nature of what is semiotic and social, the external language would refer to the actual languages presented as an epiphenomenon.

N.Ellis's (1998: 657) other approach to the study of language refers to the possibility of focusing on language process and development, rather than on state description and final state: according to this view, "one cannot properly understand something without knowing how it came about." In this perspective what is social and semiotic is more prominent. Prior (2006: 55) maintains that "Sociocultural theory rejects the notion that human action is governed by some Neoplatonic realm of rules", such as linguistic rules of English. According to Vygotsky (1987), language is a semiotic tool that, unlike other culturally-elaborated tools (e.g., a shovel), is not oriented towards the external material world but to the self-regulation of higher psychological functions (voluntary memory, reasoning, etc.). While we may assume that Chomskyan tenets maintain that language supports thought, a semiotic perspective maintains that by means of languages human development starts first on the intermental plane, which, through a process of internalization, gives way to an intramental plane (cf. Lantolf and Poehner, 2014: 44-49, for a revision of the notion of "internalization" and how it accounts for language acquisition).

Coseriu (1991) considers that while languages are "techniques" historically determined by speakers, speakers will assume the idiomatic tradition of their community. This resonates with Leontiev (1978: 51), who conceptualizes human activity as a collective process that gives a meaning to individual actions: "the activity of human individual represents a system included in the system of relationships of society. Outside these relationships human activity simply does not exist." Coseriu's idiomatic tradition would be underpinned by a permanent state of systematization, with a closed system constantly deferred. As all languages would be innovative in nature, they would be the sum of accomplished and potential possibilities. According to Halliday and Mathiessen (2004: 31), "Language is as it is because of the functions in which it has evolved in the human species."

Drawing on Humboldt (1974), Bronckart (2008: 10) argues that languages do only exist in verbal practices "in a goal-driven acting that constitutes the discourse." 
This does not mean that when a person is not speaking her language ceases to exist: rather, according to Vygotskyan tenets, it would exist on the intermental and the intramental planes. Bronckart (2008) maintains that Saussure's position, although mainly focused on the notion of "langue" as a social system, is in tune with this perspective. According to Bronckart, the Swiss linguist insisted that a foundation of this social system was "parole", which he also referred to as "discourse". The structural dimension of "parole" could only possibly be grasped in a second moment through a process of abstraction (i.e., through scientific reductionism; cf. Weigand, 2011).

Hopper (1998: 155) considers that while the image of a language in a formal theory is that of "an abstract system held together by a system of rules", an emergent perspective relocates structure from the centre to the periphery of linguistic communication. Grammar, in this view, is not the source of understanding and communication but a by-product of it: "Grammar is, in other words, epiphenomenal" (156). Hopper maintains that systematicity would be an illusion produced by the partial settling or sedimentation of frequently-used forms into temporary subsystems, and grammar would be "a vast collection of such subsystems [...] an unintended outcome of communicative behaviour" (158).

\section{Reflexivity and metalinguistic activity in language education}

In my opinion, it seems that it is from the latter perspective that reflexivity and metalinguistic activity can be considered theoretically relevant. From a genetic point of view, languages would stand as semiotic tools that would enable self-regulation and human development. This idea could also apply to the study of language itself. As a tool for thought and knowledge (Coseriu, 1991), a language would, through its reflexive affordances, shape the very process of learning the language. ${ }^{2}$

Taylor (1997: 12) maintains that the characteristics of language form can be seen as inseparable from reflexive metadiscourse: "Language could be said to have, not an internal, but an external skeleton." Taylor considers that we would manage our experience of language by means of referring to it in particular culturally-enforced and interactionally-mediated ways: "These metadiscourse-mediated analyses are as much a part of the thing (language) itself as they are about the thing itself' (16, italics in the original). This suggests that our knowledge of language is not a feature of the object (i.e., language) but a feature of our metalinguistic discourse, which serves as a semiotic mediational tool to guide our reflection.

From a Vygotskyan perspective, the notion of mediational tools can be applied to linguistic models, as devices that help us to fine-tune our metalinguistic activity. With 
regard to the school setting, French (2010: 209) points out that "since learning is mediated by tools, the kind of thought made possible by the learning process is shaped by the kind of tools available." This suggests that appropriate semiotic mediating tools delivered by teachers are at the core of the students' kind of metalinguistic activity and ultimately of the learning processes.

Models build on a set of concepts, which Vygotsky (1987) featured as either spontaneous or scientific. Miller (2011: 113) states that spontaneous concepts (e.g., flower) function "in the same way or at the same level as the more particular names for objects and substitute for the names rather than representing a higher level of organization." Conversely, "concepts that are part of a system relate to objects indirectly through other concepts that are part of a system" (e.g., flower as related to plant, vegetation, and daisy) (113). While spontaneous concepts derive from a child's personal experience and are empirical in nature and linked to specific contexts of use, scientific concepts are systematic, abstract, and generalizable, and "reveal the essential qualities of an entity or process" (Lantolf and Poehner, 2014: 60-1). From a Vygotskyan viewpoint, concepts are relevant for the formation of consciousness because they shape how we perceive, understand, and act in the world (Lantolf and Poehner, 2014).

As Lantolf and Poehner (2014: 64) point out, scientific concepts should be underpinned "by the best available information generated by the specialists through the systematic analysis of a particular domain." However, these authors maintain that, as culturally-elaborated constructs, models ought to undergo a constant process of criticism or else they may reify. This suggests that in the context of school we may perceive specific models as being intrinsically adequate to solve our pedagogic goals. But as culturally elaborated devices, linguistic models may respond to the goals of linguistics rather than to the goals of education. A process of scrutiny may enable us to work out which concepts within different models may best serve pedagogic needs (cf. Camps, 2011).

Some concepts elaborated within formal sentence-based models (e.g., complementary distribution, noun phrase, hierarchy, left-dislocation) may form microsystems that are adequate to help students disentangle sentence-level issues in writing (e.g., silent agreements in French, cf. Nadeau and Fisher, 2011). Other concepts further expanded within lexical approaches to syntax (e.g., double object construction) can help students explore the concept of transitivity (which may be useful in exploring the use of certain pronouns, e.g., in a bilingual Catalan-Spanish setting, cf. Fontich, 2014). Concepts worked out in enunciative models (e.g., addressee, adequacy, cohesion, genre) can help disentangle problems related to lexical choice or 
verb tenses (e.g., when writing different genres, cf. Myhill et al. 2012). Therefore, attention to different aspects of the system may be equally necessary and in each case we may need to draw on concepts rooted in different linguistic models.

If we consider language reflexivity an important issue in learning how to master language use, it seems reasonable to teach students how to become engaged in metalinguistic activity.

\section{Learning to engage in metalinguistic activity}

Some studies reveal that it is unrealistic to expect engagement in fruitful metalinguistic activity simply by delivering adequate scientific concepts to students (cf. Ribas et al. 2014). Linguists engage in metalinguistic activity in the form of observation, discussion, contrast, classification, etc. within specific discourse communities. This resonates with Pea's (1993: 271) sociocultural position, according to which "Expertise is defined dynamically through continuing participation in the discourse of a community" (quoted in Mercer, 2013: 154). However, it seems that we expect students to learn otherwise: as Gomila (2009: 96) ironically points out, “L'apprenti grammairien est tout sauf un linguiste..." [The grammarian apprentice is anything but a linguist...]. While teachers' talk is central to education, this talk can sometimes hinder the very process of learning, turning it into a sort of ritual that consists of memorizing facts and engaging in actions without clearly knowing its rationale (Edwards and Mercer, 2012). Works such as those collected in Dolz and Simard (2009) consider that teachers ought to accompany their explanations in the classroom with a plethora of different measures with the aim of engaging students purposefully in the task of reflection. From a Vygotskyan perspective, this falls into the concept of mediation within the so-called "zone of proximal development".

Vygotsky (1987; cf. Miller, 2011) considers language a semiotic tool oriented towards self-regulation. Self-regulation is the result of an initially other-regulated, mediated process which falls within the zone of proximal development. Vygotsky (1978: 85) defines the zone of proximal development as "the distance between the actual development level as determined by independent problem solving and the level of potential development as determined through problem solving under adult guidance or in collaboration with more capable peers." In this mediated process, the learner surrenders her "self" and relinquishes her competence to that of a more capable "other", engaging in an other-mediated performance that leads her progressively towards a new level of understanding. This process is enacted by language and other semiotic devices (e.g., graphics), which will drive the learner through different stages of internalization and ultimately to self-regulation. 
A number of studies underpinned by Vygotskyan tenets have explored learning processes in different subjects (cf. Schwartz et al. 2009). These studies consider it important both to engage students in class discussions and to draw on teachers' explanations of students' emerging (mis)understandings. With regard to metalinguistic activity, studies such as the ones mentioned above also share this approach (Bronckart, 2008; Dolz and Simard, 2009; Andrews, 2010; Myhill, 2010; Camps, 2011; Myhill and Jones, forthcoming). A general assumption is that the learning of scientific concepts will happen within a process of metalinguistic activity, i.e., knowing these concepts would not be a pre-condition for engaging in such tasks as observation, classification, definition, revision, explanation, contrast, etc. but rather would be a consequence of it. Conversely, such a process of metalinguistic activity will in turn be fine-tuned by scientific concepts, i.e., scientific concepts would be introduced in order to prevent students from relying solely on spontaneous concepts.

On the other hand, an emergentist approach maintains that the fact that language behaviour is not "rule-governed" does not imply that language cannot be described as being "rule-like" (cf. Hopper, 1998; N.Ellis, 2008). What we call "language structure" may respond to quite different assumptions, but as teaching does not pursue any kind of ontological truth, grammar instruction should draw on the most valuable tools (e.g., explanations, concepts, graphics, procedures, etc.) that enable appropriate metalinguistic activity in the context of using a language.

This metalinguistic activity may be focused on language use or on grammar subsystems detached from language use. Yet this raises the controversial issue of decontextualized grammar. Some studies quite reasonably argue about the problems that may be entailed in exploring decontextualized grammar (e.g., difficulty in transferring grammatical knowledge to language use) (cf. Andrews, 2010). In the context of teaching writing, Myhill (2010: 144-5) points out that writing as a communicative act "should be the principal pedagogic focus, and any attention to grammar should inform this, rather than using writing as useful context to deliver grammatical learning objectives."

Nevertheless, while broadly sharing this position, Camps (2011) indicates that exploring grammar only within the incessant flux of language use raises various questions as to how best to help students to build a coherent and systematic set of concepts. She maintains that the study of certain concepts (e.g., transitivity), temporarily detached from language use, can be beneficial for metalinguistic activity once they are re-engaged in the context of language use. This resonates with Vygotsky's (1987: 191) claim that "Only within a system can the concept acquire conscious awareness and a voluntary nature."3 
Camps maintains this idea, drawing on Ricoeur's (1991) position regarding hermeneutics as a procedure for description and understanding in social sciences. According to Ricoeur, human action "may become an object of science, without losing its character of meaningfulness, through a kind of objectification similar to the fixation that occurs in writing" (151). Thus the action becomes "a delineated pattern that has to be interpreted according to its inner connections" (151). This is also the position held by Hudson (forthcoming: 15):

If grammar is only taught when it is directly relevant to a writing task, then there is essentially no systematic teaching about grammar because the teacher has to provide whatever knowledge about grammar is needed at the time. Whether and how the new item of knowledge relates to the items that students know already is a matter of chance, so the students' understanding of grammar is unlikely to be more than an unstructured list of unrelated items.

Interestingly, Hudson and Camps adopt differing approaches to the study of language (formal and cognitive linguistics, and sociocultural psychology, respectively), which suggests that dissimilar ontological approaches to language need not be an obstacle for relying on specific research outcomes, as long as they are relevant for metalinguistic activity and ultimately for language use.

The interplay between procedural and declarative grammar knowledge has been a focus of interest and concern. Studies in French-, English-, and Catalanspeaking areas have explored students' grammar concepts in relation to issues such as subject, direct object, aspect, tense, noun, pronoun, adverb, and adjective (see Fontich and Camps, 2014). They reveal a gap between procedural and declarative knowledge, and a lack of capacity to establish links between them on the part of both teachers and students. Students' grammar knowledge appears to be divided into two different realms, and these studies suggest the difficulty of establishing any sort of causality between declarative and procedural knowledge. Some of the studies conducted by GREAL show that students use various strategies when speaking about a grammar issue or when completing a grammar identification task. Notario (2001) maintains that students are capable of defining a subject in terms of noun-verb agreement, but in identifying the subject of a sentence they rely on procedures based on position and pragmatics (the topic). Furthermore, Gonzalvo and Camps (2003) point out that this gap remains constant across school years.

Nevertheless, in a study of students' concepts about pronouns, Camps (2000) found that students' definition of pronouns as those words that substitute for other words did seem to condition their procedures in highlighting the pronouns in a text. One student did not highlight the pronoun "jo" (nominative first person pronoun in Catalan), justifying this by saying (correctly) that this word cannot possibly substitute for a noun, 
since any noun replacing it would immediately convert the noun-verb first person agreement into a third person agreement. Interestingly, while this student (a low achiever) seemed able intuitively to grasp the deictic nature of first person pronouns, he maintained the narrow scholarly definition he had previously given, which seemed to hinder the possibility of incorporating this new, more finely-grained feature of pronouns. Another student highlighted all the verbs since, as he said, the verbs allow us not to refer to the noun (i.e., the subject) and are therefore "substitutes for the noun". This is a reaction to a feature of some pro-drop languages (such as Catalan and Spanish), in which the subject is uttered in cases of misunderstanding or emphasis. However, the response of the student (also a low achiever) is not random, but somehow coheres with the definition explicitly provided by the teacher.

These two examples suggest that there is probably a connection between procedural and declarative knowledge, although it cannot be referred to in terms of a clear causality. The studies referenced above have examined the declarativeprocedural knowledge gap in tasks focused on exploring the grammar system, but have paid less attention to its interplay in the context of writing (see Ciapuscio, 2002). By exploring students' metalinguistic activity in the context of writing, we may reach a better idea of the problems they encounter in their reasoning. As Myhill (2010: 144) notes, understanding "the difficulties children face in learning how to create and shape meaning in written form is supportive knowledge for informing decision-making about teaching strategies and content."

\section{Metalinguistic activity in learning to write}

As indicated at the start of this paper, my intention is to present a study conducted by GREAL about metalinguistic activity, that of Camps et al. (2000). It has inspired a number of subsequent studies focused on metalinguistic activity in relation to issues such as: the learning of grammar concepts (e.g., pronoun, subjunctive, transitivity), the use of past tenses in narrative texts, the use of metalanguage in primary school, and how syntax is presented in textbooks, among other issues (e.g., cf.Milian, 2005; Ribas et al. 2014).

Camps et al. (2000) analyzed the collaborative talk of secondary students (12 to 15 year-olds) engaged in writing argumentative texts. Students were placed in six small groups (from two to three members in each) and worked within a project in Subject Catalan carried out in three schools in Barcelona (Spain). Each school had a different Instructional Sequence (see Table 1). 
Discrimination against women, especially in the professional world, was the topic content of the Instructional Sequence in Schools 1 and 2. Students in School 1 had to reply to a controversial "Letter to the Editor" published in a well-known newspaper. The opinions formulated resulted in a letter to be sent to the newspaper as a reply to the initial letter. Students in School 2 engaged in discussions about the topic, drawing on different texts and fact-sheets delivered by the teacher; as a result, a dossier was compiled with texts to be published in a magazine for young readers. In School 3, the students visited an advertising agency, where they could observe the argumentative relationship between advertiser-manufacturer-consumer. They were then to choose an advertisement and act as (fictitious) advertising agents trying to convince the manufacturer of the efficacy of their proposal in influencing the target consumers.

Table 1. Characteristics of the students and the Instructional Sequence

\begin{tabular}{|c|c|c|c|c|c|c|c|}
\hline School & Level & Ages & Groups & Genre & Objective & Addressee & Topic content \\
\hline 1 & $\begin{array}{c}2^{\text {nd }} \\
\text { ESO }\end{array}$ & $\begin{array}{c}13-14 \\
\text { years }\end{array}$ & I and II & Letter & Publication & $\begin{array}{c}\text { Newspaper } \\
\text { readers }\end{array}$ & $\begin{array}{c}\text { Women at } \\
\text { work }\end{array}$ \\
\hline 2 & $\begin{array}{c}2^{\text {nd }} \\
\text { BUP }\end{array}$ & $\begin{array}{c}15-16 \\
\text { years }\end{array}$ & $\begin{array}{c}\text { III and } \\
\text { IV }\end{array}$ & Column & Publication & $\begin{array}{c}\text { Magazine } \\
\text { readers }\end{array}$ & $\begin{array}{c}\text { Women at } \\
\text { work }\end{array}$ \\
\hline 3 & $\begin{array}{c}7^{\text {th }} \\
\text { EGB }\end{array}$ & $\begin{array}{c}12-13 \\
\text { years }\end{array}$ & $\begin{array}{c}\text { V and } \\
\text { VI }\end{array}$ & Report & Simulation & $\begin{array}{c}\text { Product } \\
\text { manufacturers }\end{array}$ & $\begin{array}{c}\text { Proposed } \\
\text { advertisement }\end{array}$ \\
\hline
\end{tabular}

Levels: ESO: Educación Secundaria Obligatoria, Secondary Compulsory Education; BUP: Bachillerato Unificado Polivalente, Polyvalent Unified Baccalaureate; EGB: Educación General Básica, Basic General Education.

The researchers were interested in describing the content of the students' metalinguistic activity, and the extent to which this activity could be related to the instructions delivered by the teachers, especially with regard to the (simulated) communicative situation which was thought to favour attention to discursive features. The assumption was that exploring students' metalinguistic activity might help in understanding the learning process and ultimately to fine-tuning this instruction.

The analysis focused on the process of composing an initial draft. This process can be divided into "episodes", where an episode is defined as an interaction in which students centre their attention on a specific issue. Analysis of these episodes is based in two units: oral reformulations of the text and utterances with metalinguistic function (cf. also Milian, 2005). As I will discuss, a relationship was established between reformulations and utterances, suggesting a possible link between procedural and verbalized knowledge.

\section{Reformulation of the text as a sign of metalinguistic activity}


Students participate actively in the process of writing through shaping and reshaping the text. The analysis identifies two types of utterances within this process: attempted texts (utterances of the-text-to-be-written) and written text (utterances repeating the actual writing). As the attempted text is meant to be written, it stands in between the oral and the written modes, as a written text still "in the air". The final written utterance results from the contributions of more than one of the group members to reformulating the attempted texts, with implicit (in the form of acceptance or refusal) and/or explicit judgements (with or without metalinguistic terms). An analysis of these reformulations suggests that they are a sign of metalinguistic activity.

The following episode (Table 2; attempted text and reformulations in bold) shows the discussion that ends with the sentence "Mainly these last ones, since the price is quite expensive and this makes fewer young people buy it." The reformulations vary in terms of quality and quantity. We may find direct reformulation without any comment or justification and some reformulations accompanied by comments:

Table 2. A dialogue in the context of writing

370. O: ... principalment aquests últims perquè el preu no sé què no sé quantos... (...mainly these last ones, since the price and so on and so forth...)

371. X: sí (yes)

372. O: [proposes]... tot i que no cal descartar els joves perquè... l'esperit d'aventura d'aquesta marca... doncs... inspira...així... joventut, per exemple (... even though it is not necessary to leave young people out because... this brand's adventure spirit... well... inspires... like that... youth, for instance)

373. X: sí, sí, ja [proposes] principalment aquest últim (yes, yes, well [proposes] mainly this last one...)

374. $0: x x x$

375. $X$ : aquests $O$ aquest? no, ja, ja, però aquests $O$ aquest $[\ldots]$ aquest $O$ aquests? (these or this?, no, listen, but these or this? [...] this or these?)

376. O: aquests (these)

377. $\mathrm{X}$ : aquest $\mathrm{O}$ aquests (this or these?)

378. O: aquests, no: aquest, bueno és igual (these, no: this, well, it doesn't matter)

379. X: és igual [repeats aloud to hear how it sounds] aquest últim... no, aquests últims, coma (no big deal [repeats etc.] this last one... no: these last ones, comma.

380. O: aquests... (these...)

381. X [writes]... últims... sobre, ah, no: principalment aquests últims, coma (last ones... on, ah, no: mainly these last ones, comma)

382. O: [proposes] ja que... (... since...)

383. $X: \ldots$ ja que el preu és bastant alt (... since the price is quite high...)

384. O: posem-ho amb paraules científiques, o... elevat, o... (better use academic words, or... inflated or...

385. X: [accepts the proposition] ... és bastant elevat... (...is quite inflated...)

386. O: ... bastant elevat... i els joves d'avui en dia no... [laughter] (quite inflated... and present-day young people can't... [laughter])

387. X: has semblat la meva àvia, tia...és bastant elevat...i... $\mathbf{i}$... (gosh, you echoed my grandma...is quite inflated and... and...)

388. O: ... i... (... and...) 


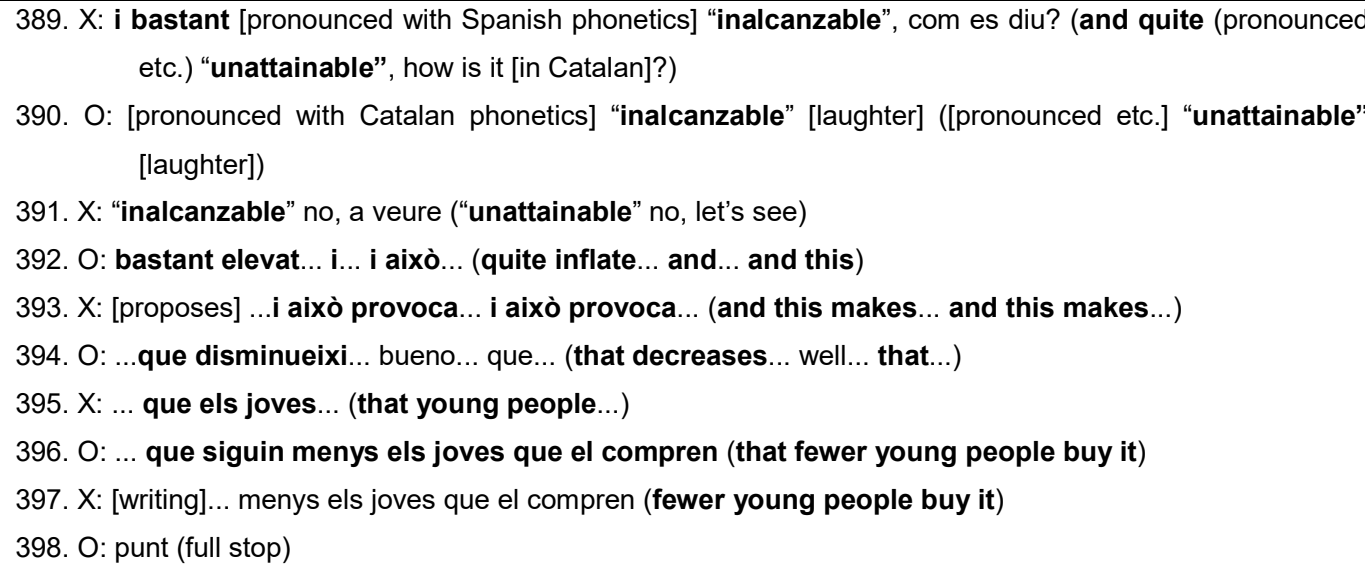

Exploring the process followed by all the groups, reformulations are categorized (Table 3) according to whether or not they are accompanied by any comment and whether or not this comment is made in specific metalanguage. While the whole process in itself is clearly a metalinguistic activity (showing students' perception of textual problems), students rarely justify the options they take with specific metalanguage, i.e., instances of type [d] are scarce:

Table 3. Varieties of reformulation

\begin{tabular}{|c|c|}
\hline Varieties of reformulation & Examples \\
\hline $\begin{array}{l}\text { [a] Simple reformulation without } \\
\text { any intermediate step between } \\
\text { one wording and the next }\end{array}$ & $\begin{array}{l}218 \text { X: aquest anunci que presentem a... (this advertisement which we } \\
\text { are presenting to...) } \\
219 \text { O: I'anunci que presentem en... (the advertisement we are } \\
\text { presenting in...) }\end{array}$ \\
\hline $\begin{array}{l}\text { [b] Reformulation with explicit } \\
\text { negation prior to the proposed } \\
\text { form, or expression of doubt that } \\
\text { sometimes leads towards intense } \\
\text { comparison between forms, but } \\
\text { without any verbalized } \\
\text { metalinguistic reflection }\end{array}$ & $\begin{array}{l}457 \text { O: .... la gent ja esmentada fumadora... no sé, com ho veus? } \\
\text { (...to the people mentioned above as smoking people... I don't know, } \\
\text { what do you think?) } \\
458 \text { X: fumadora, no, als fumadors, és que a la gent, no, als } \\
\text { fumadors... (smoking people, no, to the smokers, I mean, to the } \\
\text { people, no, to the smokers...) } \\
459 \text { O: ja esmentats (already mentioned) } \\
460 \text { X: al target! (to the target! [sic]) } \\
461 \text { O: jo! (gosh!) } \\
462 \text { X: ....al target, al target... (... to the target, to the target [sic]) } \\
463 \text { O: ...ja esmentat abans (...already mentioned above) }\end{array}$ \\
\hline $\begin{array}{l}\text { [c] Reformulation and/or } \\
\text { comparison with explicit reflection } \\
\text { but without using specific } \\
\text { metalanguage }\end{array}$ & $\begin{array}{l}526 \text { O: a veure... com es veu... (let's see... as one can see...) } \\
527 \text { X: a veure... en l'anunci es podrà veure... } \\
\text { (let's see... in the advertisement one will be able to see...) } \\
528 \text { O: com es podrà veure en... ai, no! (as one will be able to see } \\
\text { in... no, no!) } \\
529 \text { X: no, o sigui, perquè com que encara no està... (yeah, I mean, } \\
\text { because it's not out yet...) }\end{array}$ \\
\hline $\begin{array}{l}\text { [d] Reformulation and/or } \\
\text { comparison with explicit reflection } \\
\text { using specific metalanguage }\end{array}$ & $\begin{array}{l}\text { 383. X: ... ja que el preu és bastant alt (... since the price is quite } \\
\text { high...) } \\
\text { 384. O: posem-ho amb paraules científiques, o... elevat, o... (better use }\end{array}$ \\
\hline
\end{tabular}


academic words, or... inflated or...)

385. X: [accepts the proposition] ... és bastant elevat... (...is quite inflated...)

Table 4 shows the skeleton of a reformulation process, focusing solely on the utterances that express the attempted text as well as the text being written. (In order to graphically represent how the text keeps evolving, only the English translations of the Catalan utterances are given here.) Two girls are placed in a fictional situation where they are acting as an advertising firm:

Table 4. Reformulation process

\begin{tabular}{|c|c|c|c|c|c|c|}
\hline Turn- Student & \multicolumn{6}{|c|}{ Reformulations } \\
\hline $566-A$ & - & we will & utterly & highlight & & \\
\hline & this & will be & & highlighted & & \\
\hline $568-B$ & the price & & & & & \\
\hline $569-A$ & the price & will & & appear & & \\
\hline $570-B$ & - & will & clearly & appear & & \\
\hline $572-A$ & - & - & & & because & it is the differential profit \\
\hline $573-B$ & - & - & & & because & differential \\
\hline Final text & The price & will & clearly & appear & because & it is the differential profit \\
\hline
\end{tabular}

These students are preparing a report to the customer for a publicity proposal and are trying to support it with some convincing reasons. A first utterance (566. we will utterly highlight) is followed by two reformulations. An initial one avoids the use of "we" and impersonalizes the sentence with a passive (566. this will be highlighted). This suggests that they aim at decontextualizing the text in relation to the physical context of production. This move is further enhanced by dismissing the passive and thus contributing to leaving the speakers/writers out of the report (569. the price will appear). A second reformulation aims at recontextualizing the meaning of "this": since the readers will not actually have the page with the advertisements already published, the writers have to state the referent explicitly (568. the price). The rest of the text causes no problems, the proposals being repeated by the partner as an acceptance (570) and accompanying the act of handwriting the text (573). We can conjecture that the complexity of the textualization operation triggers metalinguistic activity, in the form of reformulations that seem to respond to different needs, as we will see below.

\section{The different meanings of reformulations}

Reformulations seem to fit around three general meanings. First, they may respond to the adequacy of the written mode. An "attempted text" has the features of the written 
mode, but since it is uttered it still includes some oral elements. Members of the group detect this mismatch and try to reproduce a more standard form of writing. Some reformulations are lexical and seek a more fine-grained vocabulary (e.g., "we agree $\rightarrow$ we are in favour of $\rightarrow$ we support"; "grandparents $\rightarrow$ elderly people $\rightarrow$ third generation people $\rightarrow$ people (who are) advanced in years"). Some others are syntactic, such as relying on passivisation (e.g., "nature has already imposed $\rightarrow$ they are already imposed by nature"; "we find $\rightarrow$ it is found"). Also, some are oriented to avoid redundancies (e.g., "we can say this in one word $\rightarrow$ in one word"). Finally, some reveal awareness of text autonomy with regard to students' actual context. An example is the use of deictics to refer to the on-going discussion. This text about women and the labour market, "everything progresses except this", is reformulated and ends up making explicit reference to the female condition of the three members of the group, all of them girls: "except this $\rightarrow$ except the most important $\rightarrow$ except women $\rightarrow$ except us, the most important".

Secondly, reformulations may also aim at accommodating the rhetorical context. Because the assignments were based on producing argumentative texts, when the addressees are young students, text proposals will tend to use colloquial language. The follow up to this piece of text about discrimination against women: "A man sitting on an armchair. A pint on his hands. Football on TV. At the same time someone is moving around the kitchen. I would bet it's a woman!", triggers the following reformulation: "what does this mean? $\rightarrow$ what are you saying, guy!? it can't be like that $\rightarrow$ what are you saying, man!? $\rightarrow$ do you think $? \rightarrow$ do you think it's a woman? $\rightarrow$ do you think?". Also, reformulations seem to be oriented towards making the text more convincing (e.g., "we are not in favour of sexism $\rightarrow$ as women, we are not in favour of sexism"; "we want a neutral situation $\rightarrow$ we don't want a radical situation").

And finally, some reformulations are evidence of students seeking the best way to express ideas, such as this one about women and the labour market: "to have a job and to be a housewife $\rightarrow$ to have two jobs $\rightarrow$ to have several jobs $\rightarrow$ to have more than one job $\rightarrow$ to have several jobs $\rightarrow$ to have more than one job, but at the same time". Students try to find what they want to express, and this may be a consequence of explicit work in the Instructional Sequence devoted to generating content on the topic. The need to explain specific ideas may trigger and enhance students' metalinguistic activity, establishing a dialectical relationship between topic contents and the linguistic and textual forms. 


\section{Utterances with metalinguistic function}

Apart from metalinguistic comments that accompany reformulations, students can also focus on the text by means of metalinguistic comments with no direct link to textproduction. These comments serve to take the text as an object to reflect upon explicitly: in the analysis they are called "metalinguistic utterances" to differentiate them from comments that accompany reformulations. Metalinguistic utterances may be correct or not, or may be formulated or not in specific terms, and seem to fulfil the function of referring to linguistic use in a broad sense (e.g., to the linguistic system, to the addressee, etc.). Leaving aside utterances on topic contents, Table 5 presents six kinds of metalinguistic utterances, as well as the results of the analysis of the six groups of students:

Table 5. Metalinguistic utterances (MU)

\begin{tabular}{|c|c|c|c|c|c|c|c|}
\hline \multirow[b]{2}{*}{ Kinds of $M U$} & \multicolumn{6}{|c|}{ Metalinguistic Utterances per Group } & \multirow{2}{*}{$\begin{array}{c}\text { Total } \\
M U\end{array}$} \\
\hline & $\begin{array}{c}\text { Group } \\
I\end{array}$ & $\begin{array}{c}\text { Group } \\
/ /\end{array}$ & $\begin{array}{c}\text { Group } \\
\text { III }\end{array}$ & $\begin{array}{c}\text { Group } \\
\text { IV }\end{array}$ & $\begin{array}{c}\text { Group } \\
V\end{array}$ & $\begin{array}{c}\text { Group } \\
\text { VI }\end{array}$ & \\
\hline (1) Discursive features & 29 & 10 & 8 & 1 & 5 & 7 & 60 \\
\hline (2) Textual structure & 49 & 8 & 94 & 36 & 92 & 85 & 364 \\
\hline (3) Linguistic aspects & 37 & 6 & 35 & 0 & 41 & 42 & 161 \\
\hline (4) Spelling & 15 & 0 & 30 & 0 & 3 & 3 & 51 \\
\hline (5) Punctuation & 9 & 0 & 15 & 2 & 11 & 7 & 44 \\
\hline (6) Evaluations & 2 & 1 & 7 & 0 & 3 & 1 & 14 \\
\hline Total MU & 141 & 25 & 189 & 39 & 155 & 145 & 694 \\
\hline Total turns & 471 & 227 & 952 & 674 & 871 & 923 & - \\
\hline Percentage of $M U$ & 29.9 & 11 & 19.8 & 5.8 & 17.7 & 15.7 & - \\
\hline
\end{tabular}

All groups formulated explicit metalinguistic utterances, although not to the same extent. As can be seen, the highest number refers to (2) Textual structure, a central aspect in the project on argumentative texts (e.g.,628 P: és que ara, per exemple, després d'això podríem dir per exemple, hi ha grups que..'; 628 P: but now, probably, after this we could say for instance, there are groups that...). However, utterances about (4) Spelling and (5) Punctuation are scarce, as students may feel that in a first draft this is a secondary issue (e.g., 644 R: er-ròooo... errò-ni-a, 645 P: ònia... ha de ser amb 'o' oberta; 644 R: err-0oo... errooo-ne-ous, 645 P: oneous... you must write an 'o'; e.g., 648 E: a veure, exemple d'una situació errònia, 649 P: dos punts, i ara què diem?, la gent...; $648 \mathrm{E}$ : let's see, an example of an erroneous situation, $649 \mathrm{P}$ : colon, and now, what should we say?, the people...). Nor are there many evaluative utterances (6. Evaluations): the analysis shows that they tend to appear only in single 
turns and very few appear with a reply (e.g., $628 \mathrm{P}$ : per exemple, hi ha alguns grups neonazis (laughing) i dir ahhh puhhh (making a shooting sound), no, no funciona la qüestió dels Nazis, 629 E: no, els Nazis no; 628 P: for example, there are some neonazi groups (laughing) and say ahhh puhhh (making etc.), no it doesn't work, the issue of the Nazis, $629 \mathrm{E}$ : no, the Nazis no). On the other hand, utterances categorised as (3) Linguistic aspects reveal that metalanguage is rarely used and refers mostly to lexical aspects (e.g., a more adequate word: $650 \mathrm{E}$ : con... oh! conseqüentment o... com és?, $651 \mathrm{P}$ : posteriorment; $650 \mathrm{E}$ : con... oh! consequently or... how is it?, $651 \mathrm{P}$ : subsequently), with scarcely any references to morpho-syntax (e.g., use of the passive).

Finally utterances referred to as (1) Discursive features are relatively low, something that can be considered as unexpected, given the (simulated) communicative situation which was thought to favour it (e.g., 669 P: un doctorat en psicologia, ella té un doctorat en medicina, 670 E: això, això, això, això, tens raó, ho hem de justificar, hem de dir algun nom perquè la gent ens faci cas; $669 \mathrm{P}$ : a PhD in psychology, she has a PhD in medicine, $670 \mathrm{E}$ : right, right, right, you're right, we need to justify it, we have to say the name of somebody so that the people pay attention). However, as we have seen, analysis of the reformulations (see above) does show that metalinguistic activity regarding discursive features manifests at a procedural level, and through metalinguistic comments accompanying reformulations. Thus, the presence of discourse aspects through these procedural moves reveals that learning targets may appear not only verbalized but also on a procedural level.

In this respect, there seems to be a link between the number of reformulations and the number of metalinguistic utterances. Placing the mean of reformulations per episode in relation to the percentage of metalinguistic utterances (as presented in Table 5) seems to indicate that there is a close relationship between verbalized metalinguistic activity (i.e., metalinguistic utterances) and procedural activity (i.e., reformulations) in the writing process (Table 6), although groups I and III do not wholly support this relationship:

Table 6. Metalinguistic utterances (MU) and reformulations

\begin{tabular}{|l|c|c|c|c|c|c|}
\hline & $\begin{array}{c}\text { Group } \\
I\end{array}$ & $\begin{array}{c}\text { Group } \\
I I\end{array}$ & $\begin{array}{c}\text { Group } \\
I I I\end{array}$ & $\begin{array}{c}\text { Group } \\
I V\end{array}$ & $\begin{array}{c}\text { Group } \\
\text { V }\end{array}$ & $\begin{array}{c}\text { Group } \\
\mathrm{VI}\end{array}$ \\
\hline $\begin{array}{l}\text { Episodes with } \\
\text { reformulations }\end{array}$ & 4 & 5 & 6 & 4 & 18 & 15 \\
\hline $\begin{array}{l}\text { Total of } \\
\text { reformulations }\end{array}$ & 68 & 43 & 157 & 27 & 309 & 256 \\
\hline $\begin{array}{l}\text { Mean of } \\
\text { reformulations }\end{array}$ & 17 & 8.6 & 26.16 & 6.75 & 17.16 & 17.06 \\
\hline
\end{tabular}




\begin{tabular}{|l|c|c|c|c|c|c|}
\hline per episode & & & & & & \\
\hline $\begin{array}{l}\text { Percentage of } \\
\text { MU }\end{array}$ & 29.9 & 11 & 19.8 & 5.8 & 17.7 & 15.7 \\
\hline
\end{tabular}

This shows that the groups who are able to talk to a greater extent about the textbeing-written can also reformulate to a greater extent. Admittedly, this analysis cannot establish any sort of causal relationship between these two outcomes, and subsequent studies conducted by GREAL have shown the difficulties students experience in transferring declarative into procedural knowledge and vice versa (cf. Ribas et al. 2014). This suggests that further research should be conducted in order to disentangle the ways in which students' procedural and declarative knowledge, which apparently fit into different realms, might interpenetrate each other.

\section{Metalinguistic activity as a focus for teaching and learning and research}

The role of metalinguistic activity in writing suggests the following question: "Does metalinguistic activity lead students to write better texts?" According to Camps et al. (2000) and subsequent studies such as Rodríguez Gonzalo (2014) the answer might be negative. Rodríguez Gonzalo (2014) emphasizes the extent to which students are intensely engaged in metalinguistic activity. Their attention is focused on important issues highlighted by the teacher, such as verb tenses. However, when deciding which element scrutinized in the discussion will finally stand as "written text", students do not always choose the best solution, and may therefore end up writing bad texts.

Notwithstanding, by tracking their conversations, Rodríguez Gonzalo shows that students' metalinguistic activity is penetrated by an issue that is crucial in educating good writers: the capacity to endure a constant process of shaping and reshaping the outcomes of writing, i.e., of engaging in a sustained metalinguistic activity (also an outcome quite apparent in Camps et al. 2000). According to Carlino (2005) this is a basic skill that differentiates high and low achievers in writing: the latter take their first ideas as the last ones and are not capable of reshaping them, while the former are capable of deferring the moment when the text is considered completed (cf. Pritchard and Honeycutt, 2006). From this perspective, the answer to the question above could be positive. Rodríguez Gonzalo (2014) shows that after an experience of collaborative writing, students are capable of improving their individual writing in respect of features that were the focus of attention (namely, the correlation of verb tenses in the past). 
The study by Camps et al. (2000) reveals that metalinguistic activity emerges in different levels of explicitness (Figure 1). The authors have considered explicit metalinguistic activity as "observable" activity: while \#1 applies to actions taken by students with regard to grammar while they are writing, \#2 and \#3 refer to what students also say while performing these actions during peer collaboration in the classroom:

Figure 1. Levels of metalinguistic activity

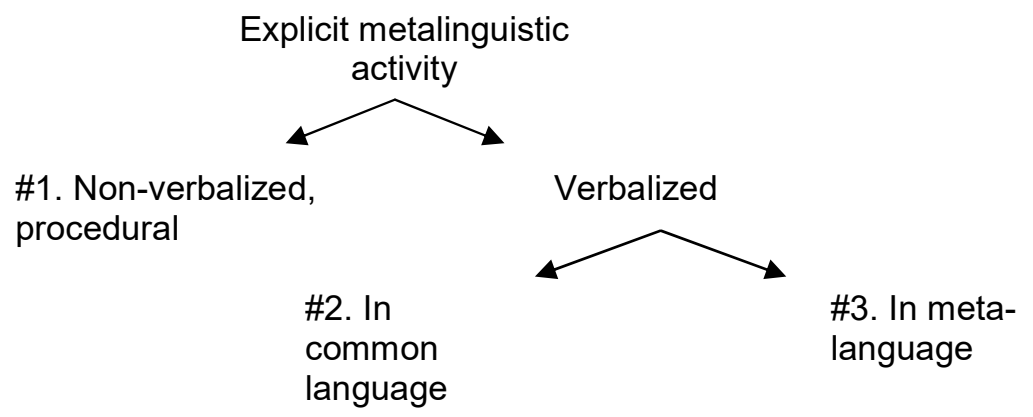

A number of studies by GREAL (e.g., Ribas et al. 2014) have reached conclusions regarding: the directionality of reflection, which can go from \#1 to \#3 and vice versa; how a misuse of metalanguage $(\# 3)$ can hinder appropriate reflections; the fact that common language (\#2) can convey adequate grammar conceptualizations; or the fact that verbalized levels (\#2 and \#3) may not stem naturally from a procedural level (\#1) (i.e., learning grammar only by writing may not be possible). They also consider that, while promoting activities of discovery and classification may trigger valuable metalinguistic activity, this is especially so when it happens within a framework such as that of Instructional Sequence.

At the beginning of this paper, I presented metalinguistic activity as a notion that could convey conceptual clarity when approaching the role played by grammar instruction in learning how to use language. It would be nonsense to state that research has never focused on how students reflect upon grammar issues in the process of language use. However, by placing metalinguistic activity within a semiotic and social approach to the study of language, it becomes theoretically prominent. Metalinguistic activity appears as a reflexive activity carried on by the learners and prompted by the teachers within the zone of proximal development through mediational tools suited to the instructional goals. While metalinguistic activity can be prompted from the very early years by means of spontaneous concepts, scientific concepts progressively introduced by the teacher will enable a more fine-tuned reflection (French, 2010; Ribas et al. 2014). From this perspective, the studies cited above consider that research on 
metalinguistic activity is an insightful avenue for teaching and learning, and for research on the interplay between grammar and language use.

\section{Short biography}

Xavier Fontich's research concerns language education, specifically grammar instruction at L1 and its connection with writing. He has authored or co-authored papers on this topic for Research Papers in Education, Textos, Lenguaje y textos, and Lectura y vida, among others. His book Hablar y escribir para aprender gramática [Speaking and writing to learn grammar] (Barcelona, 2006) argues that social interaction and writing have an enormous epistemic potential in learning grammar. $\mathrm{He}$ has recently co-edited a book for Peter Lang, Grammar at school: Metalinguistic activity in language education (Brussels, 2014) which brings together studies on the teaching of grammar in primary and secondary schools in Spain. He has published a number of works on a variety of educational issues, such as text books, literature education, and in-service teacher education. In the period 2014-2016 he is a Visiting Scholar at the Graduate School of Education, University of Exeter (UK), with a Beatriu de Pinós postdoctoral grant given by AGAUR (official agency for research, Barcelona), and in 2015 he obtains a tenure-track position at the Universitat Autonoma de Barcelona (Spain). He has developed a professional career as a secondary school teacher (1995-2014). He holds a BA in Philosophy and Language Arts (1994) and a $\mathrm{PhD}$ in Education (2010), both from Universitat Autònoma de Barcelona.

\section{Acknowledgements}

I extend my thanks to Anna Camps for her support over the past years and to Maya Honda for inviting this submission and for helping during the process. Also to two anonymous referees for their detailed commentary and suggestions. This paper has been much improved as a consequence. Remaining limitations or errors are mine.

\section{Works cited}

Andrews, Richard. 2010. Teaching sentence-level grammar for writing: The evidence so far. Beyond the grammar wars: A resource for teachers and students on developing language knowledge in the English/Literacy classroom, ed. by Terry Locke, 91-108. London: Routledge.

Bronckart, Jean-Paul. 2008. Actividad lingüística y construcción de conocimientos [Linguistic activity and the construction of knowledge]. Lectura y vida: Revista latinoamericana de lectura 29 (2). 6-19.

Camps, Anna. 2000. El coneixement gramatical dels alumnes: El cas dels pronoms personals [Students' grammar knowledge: The case of personal pronouns]. La terminologia lingüística en l'ensenyament secundari: Propostes pràctiques [Linguistic terminology in secondary school: Practical issues], ed. by Jaume Macià and Joan Solà, 121-136. Barcelona: Graó.

----. ed. 2003.Secuencias didácticas para aprender a escribir [Instructional sequences to learn writing]. Barcelona: Graó.

----. 2011. Intervenció, innovació i investigació: Una relació necessària per a les didàctiques [Intervention, innovation, and research: A necessary relationship for didactics]. L'activitat docent: Intervenció, innovació, investigació [Teaching activity: Intervention, innovation, and research], ed. by Joan Vallès, Dolores Álvarez Rodríguez, and René Rickenmann, 115-24. Girona: Documenta Universitaria.

----. 2014. Metalinguistic activity in language learning. Grammar at school: Metalinguistic activity in language education, ed. by Teresa Ribas, Xavier Fontich, and Oriol Guasch, 23-40. Brussels: Peter Lang.

Camps, Anna, Oriol Guasch, Marta Milian, and Teresa Ribas. 2000. Metalinguistic activity: The link between writing and learning to write. Metalinguistic activity in learning to write, ed. by Anna Camps and Marta Milian, 103-24.Amsterdam: AUP. 
Camps, Anna, and Felipe Zayas, eds. 2006. Secuencias didácticas para aprender gramática [Instructional sequences for learning grammar]. Barcelona: Graó.

Carlino, Paula. 2005. Escribir, leer y aprender en la universidad: Una introducción a la alfabetización académica [Writing, reading, and learning at the university: An introduction to academic literacy]. Buenos Aires: Fondo de Cultura Económica.

Chomsky, Noam. 1977. Knowledge and responsibility. New York: Pantheon Books.

---. 1986. Knowledge of language: Its nature, origin, and use. Westport, CT: Greenwood Publishing Group.

Ciapuscio, Guiomar. 2002. El lugar de la gramática en la producción de textos [The place of grammar in text production]. Simposio internacional Lectura y Escritura: Nuevos desafíos [International symposium Reading and Writing: New challenges]. Facultad de Educación Elemental y Especial: Universidad Nacional de Cuyo.

Cole, Michael. 2010. Cultural-historical activity theory. Qualitative research, 360-66. Philadelphia: Elsevier.

Coseriu, Eugenio. 1991. El hombre y su lenguaje [Man and his language]. Madrid: Gredos.

Dolz, Joaquim, and Claude Simard, eds. 2009. Pratiques d'enseignement grammatical: Points de vue de l'enseignant et de l'élève [Practices of grammar instruction: Teacher and student perspectives]. Québec: PUL.

Edwards, Derek, and Neil Mercer. 2012. Common knowledge: The development of understanding in the classroom. London: Methuen/Routledge.

Egar, Kieran. 2009. Students' development in theory and practice: The doubtful role of research. Educational theories, cultures, and learning, ed. by Harry Daniels, Hugh Lauder, and Jill Porter, 54-67. London: Routledge.

Ellis, Nick. 1998. Emergentism, connectionism and language learning. Language Learning 48 (4). 631-664. DOI:10.1111/0023-8333.00063.

---. 2008. Implicit and explicit knowledge about language. Encyclopaedia of language and education ( $2^{\text {nd }}$ Edition), Vol 6, ed. by Jasone Cenoz and Nancy H. Hornberger, 1-13. New York: Springer.

Ellis, Rod. 2006. Current issues in the teaching of grammar: An SLA perspective. TESOL Quarterly 40 (1), 83-107. DOI:10.2307/40264512

----. 2010. Explicit form-focused instruction and second language acquisition. The handbook of educational linguistics, ed. by Bernard Spolsky and Francis M. Hult, 437-55.Oxford: Wiley-Blackwell.

Fontich, Xavier. 2014. Le verbe, centre de la phrase: Les étudiants classent des verbes en prenant compte des compléments verbaux [The verb, centre of the sentence: Students classify verbs taking into account verb complements]. Le verbe en toute complexité: acquisition, transversalité et apprentissage [The verb in all its complexity: Acquisition, transversality, and learning], ed. by Corinne Gomila and Dominique Ulma, 189-204. Paris: L'Harmattan.

Fontich, Xavier, and Anna Camps. 2014. Towards a rationale for research into grammar teaching in schools. Research Papers in Education 29 (5). 598-625. DOI:10.1080/02671522.2013.813579.

French, Ruth. 2010. Primary school children learning grammar: Rethinking the possibilities. Beyond the grammar wars: A resource for teachers and students on developing language knowledge in the English/Literacy classroom, ed. by Terry Locke, 206-29. London: Routledge.

Gombert, Jean-Émile. 1992. Metalinguistic development. Chicago: University of Chicago Press.

Gomila, Corinne. 2009. Premières interventions grammaticales pratiquées lors de l'enseignement de la lecture au Cours préparatoire (CP) [First grammar interventions practised in the teaching of reading to preparatory courses]. Pratiques d'enseignement grammatical: Points de vue de l'enseignant et de l'élève [Practices of grammar instruction: Teacher and student perspectives], ed. by Joaquim Dolz and Claude Simard, 75-98. Québec: PUL.

Gonzalvo, Laura, and Anna Camps. 2003. Els conceptes metalingüístics dels alumnes de secundària: El subjecte [Metalinguistic concepts of secondary students: The subject]. Articles de didàctica de la llengua i la literatura 31. 111-123.

Gutiérrez, Xavier. 2008. What does metalinguistic activity in learners' interaction during a collaborative L2 writing task look like? The Modern Language Journal 92 (4). 519-37. DOI:10.1111/j.1540-4781.2008.00785.x 
Halliday, Michael A.K., and Christian Matthiessen. 2004. An Introduction to Functional Grammar ( $3^{\text {rd }}$ Edition). London: Hodder Education.

Hopper, Paul J. 1998. Emergent grammar. The new psychology of language, ed. by Michael Tomasello, 155-75. Mahwah, NJ: Lawrence Erlbaum.

Hudson, Richard. 2010. Linguistic theory. The handbook of educational linguistics, ed. by Bernard Spolsky and Francis M. Hult, 53-65. Oxford: Wiley-Blackwell.

----. Forthcoming. Grammar instruction. Handbook of writing research ( $2^{\text {nd }}$ Edition), ed. by Charles MacArthur, Steve Graham, and Jill Fitzgerald, 1-33. London: Guilford.

Humboldt, Wilhelm von. 1974. Introduction à l'œuvre sur le kavi et autres essais [Introduction to the study of Kaviand other essays], ed. by P. Caussat. Paris: Seuil.

Jakobson, Roman. 1960. Closing statement: Linguistics and poetics. In Style in language, ed. by Thomas A. Sebeok, 350-377. Cambridge, MA: MIT Press.

Karmiloff-Smith, Annette. 1992. Beyond modularity: A developmental perspective on cognitive science. Cambridge, MA: MIT Press.

Lantolf, James P., and Matthew E. Poehner. 2014. Sociocultural theory and the pedagogical imperative in L2 education: Vygotskyan praxis and the research/practice divide. London: Routledge.

Leontiev, Aleksei N. 1978. The problem of activity in psychology. Activity, consciousness, and personality, 45-74. Translated from Russian by Marie J. Hall. Englewood Cliffs, NJ: Prentice-Hall.

Mercer, Neil. 2013. The social brain, language, and goal-directed collective thinking: A social conception of cognition and its implications for understanding how we think, teach, and learn.Educational Psychologist 48 (3). 148-68. DOI:10.1080/00461520.2013.804394

Milian, Marta. 2005. Reformulation. L1-Educational Studies in Language and Literature 5 (3). 335-51. DOI:10.1007/s10674-005-8560-9

----. 2014. Working on grammar at school. Grammar at school: Metalinguistic activity in language education, ed. by Teresa Ribas, Xavier Fontich, and Oriol Guasch, 43-74. Brussels: Peter Lang.

Miller, Ronald. 2011. Vygotsky in perspective. New York: Cambridge University Press.

Myhill, Debra A. 2010. Ways of knowing: Grammar as a tool for developing writing. Beyond the grammar wars: A resource for teachers and students on developing language knowledge in the English/Literacy classroom, ed. by Terry Locke, 129-48. London: Routledge.

Myhill, Debra A., Susan M. Jones, Helen Lines, and Annabel M. Watson. 2012. Re-thinking grammar: The impact of embedded grammar teaching on students' writing and students' metalinguistic understanding. Research Papers in Education 27 (2). 139-66. DOI:10.1080/02671522.2011.637640

Myhill, Debra A., and Susan M. Jones.2015. Conceptualising metalinguistic understanding in writing. Cultura y Educación: Culture and Education 27 (4). 839-867. DOI:10.1080/11356405.2015.1089387

Nadeau, Marie, and Carole Fisher. 2011. Les connaissances implicites et explicites en grammaire: Quelle importance pour l'enseignement? Quelles conséquences? [Implicit and explicit grammar knowledge: What importance for teaching? What consequences?] Bellaterra Journal of Teaching and Learning Language and Literature 4 (4).1-31.

Notario, Gemma. 2001. Los conceptos gramaticales de los alumnos de secundaria: El sujeto [Grammar concepts of secondary students: The subject]. El aula como espacio de investigación y reflexión [Classroom as a space for research and reflection], ed. by Anna Camps, 181-193. Barcelona: Graó.

Pea, Roy D. 1993. Learning scientific concepts through material and social activities: Conversational analysis meets conceptual change. Educational Psychologist 28 (3), 265-277. DOI:10.1207/s15326985ep2803_6

Prior, Paul. 2006. A sociocultural theory of writing. Handbook of writing research, ed. by Charles A. MacArthur, Steve Graham, and Jill Fitzgerald, 54-66. London: Guilford.

Pritchard, Ruie J., and Ronald L. Honeycutt. 2006. The process approach to writing instruction: Examining its effectiveness. Handbook of writing research, ed. by Charles $A$. MacArthur, Steve Graham, and Jill Fitzgerald, 275-90. London: Guilford.

Ribas, Teresa, Xavier Fontich, and Oriol Guasch, eds. 2014.Grammar at school: Metalinguistic activity in language education. Brussels: Peter Lang.

Ricoeur, Paul. 1991. From text to action: Essays in hermeneutics II. Translated from French by Kathleen Blamey and John B. Thompson. Evanston, IL: Northwestern University Press. 
Rodríguez Gonzalo, Carmen. 2014. Reflexive knowledge of the past tenses in Spanish. Grammar at school: Metalinguistic activity in language education, ed. by Teresa Ribas, Xavier Fontich, and Oriol Guasch, 227-55. Brussels: Peter Lang.

Roth, Froma P., Deborah L. Speece, Daniel H. Cooper, and Susan de la Paz. 1996. Unresolved mysteries: How do metalinguistic and narrative skills connect with early reading? The Journal of Special Education 30 (3). 257-77. DOI:10.1177/002246699603000303

Schwartz, Baruch, Tommy Dreyfus, and Rina Hershkowitz, eds. 2009. Transformation of knowledge through classroom interaction. London: Routledge.

Searle, John. 1995. The construction of social reality. London: Penguin.

Swain, Merrill. 2006. Languaging, agency and collaboration in advanced second language proficiency. Advanced language learning: The contribution of Halliday and Vygotsky, ed. by Heidi Byrnes, 95-108. New York: Continuum.

Taylor, Talbot J. 1997. Theorizing language: Analysis, normativity, rhetoric, history. Oxford: Pergamon Press.

---- 2000. Language constructing language: The implications of reflexivity for linguistic theory. Language Sciences 22. 483-99

----. 2014. Language in its own image: On epilinguistic and metalinguistic knowledge. Penser I'histoire de la linguistique: Études épistémologiques, historiques et linguistiques en hommage à Sylvain Auroux [Conceptualizing the history of linguistics: Epistemological, historical, and linguistic studies in honour of Sylvain Auroux], ed. by Sylvie Archaimbault, Jean-Marie Fournier, and Valérie Raby, 150-159. Lyon: ENS.

Vygotsky, Lev S. 1978. Mind in society: The development of higher psychological processes. Ed. by Michael Cole, Vera John-Steiner, Sylvia Scribner, and Ellen Souberman. Cambridge, MA: Harvard University Press.

----1987. Thinking and speech. The collected works of L.S. Vygotsky, Vol. 1: Problems of general psychology, ed. by Robert W. Rieber and Aaron S. Carton, 39-288. New York: Plenum.

Watson, Annabel M. 2015. Conceptualisations of 'grammar teaching'. Language Awareness 24 (1). 1-14. DOI:10.1080/09658416.2013.828736

Weigand, Edda. 2011. Paradigm changes in linguistics. Language Sciences 33.544-49. DOI:10.1016/j.langsci.2011.04.031

Wittgenstein, Ludwig. 1953. Philosophical investigations. Oxford: Basil Blackwell.

\section{Endnotes}

${ }^{1}$ Metalinguistic activity has also been approached with regard to L2. R.Ellis (2010: 452) considers that in form-focused instruction the characteristic that emerges as especially noteworthy is "metalinguistic activity involving such instructional strategies as providing learners with metalinguistic information [...], inviting them to discover grammatical rules for themselves, and encouraging reflection on and self-repair of their errors". He maintains that metalinguistic activity results from the interplay between explicit and implicit learning enhancing explicit and implicit knowledge. Also, drawing on studies focused on L1 such as Camps et al. (2000), Gutiérrez (2008: 521) maintains that metalinguistic activity in collaborative writing tasks in L2 settings can emerge both in explicit and implicit ways, and claims that "learners need to be provided with the appropriate tools to reflect on language and its use".

${ }^{2}$ This resonates with the notion of "languaging" as featured by Swain (2006) for L2 advanced learners drawing on a Vygotskyan perspective. It entails using language as a tool to mediate learners' thinking, triggering "a process which creates a visible or audible product about which one can language further" (97) and by which learners ultimately learn "both through and about language" (106).

${ }^{3}$ This is also R.Ellis's (2006: 103) position regarding L2 grammar instruction, which "should take the form of separate grammar lessons (a focus-on-forms approach) and should also be integrated into communicative activities (a focus-on-form approach)". 